\title{
Evaluation of Apple Pomace Based Reconstituted Feed in Rats After Solid State Fermentation and Ethanol Recovery
}

\author{
A. Devrajan ${ }^{1}$, Vinod K. Joshi ${ }^{1 *}$, Kuldeep Gupta ${ }^{2}$, Chander Sheikher ${ }^{3}$ and Brij B. Lal ${ }^{1}$ \\ ${ }^{1}$ Department of Post harvest Technolog. ${ }^{2}$ Department of Silviculture and Agroforestry. ${ }^{3}$ Department of \\ Entomology and Apiculture; Dr YSP University of Horticulture and Forestry Nauni Solan (H.P)173230; India
}

\begin{abstract}
To utilize apple pomace in an economical and effective way, a feed was developed by solid state fermentation $(S S F)$ using sequential interactive co-culture of Candida utilis and Kloeckera. Removal of ethanol and drying of the left - over residue. Feeding trial was conducted in white albino rats before and after reconstitution of apple pomace feed in the choice and no choice study. Feeding of apple pomace feed in the rats before reconstitution indicated that neither in fermented nor in unfermented form it was acceptable. In the no choice study both in $100 \%$ fermented and unfermented apple pomace group feed intake decreased continuously resulting in death of rats apparently due to decreased digestibility owing to high fibre content. Further, fermented or unfermented apple pomace based feed had lower digestibility and efficiency of conversion than the standard rat feed. Compared to the standard feed group, growth rates in all the feed groups were negative. The results of choice study of different feeds corroborated with the no-choice study mentioned earlier. Incorporation of fermented apple pomace into standard rat feed in the ratio of 1:1 gave better acceptability and digestibility. Reconstituted feed with $10 \%$ jaggery, $2 \%$ groundnut oil, $0.01 \%$ mixed flavour and $1 \%$ salt was the most acceptable. The post-mortem examination of the rats that died during the feeding trial revealed generalized oedema, probably due to some hepatotoxin in the feed. The blood glucose level in the apple pomace feed group except that was reconstituted with jaggery, showed a general hypoglycemia, though falling in the range. The increased ALT and AST levels in the serum also suggest damage to the liver. The mortality rate, post-mortem examination of the rats that died during the feeding trial and blood biochemical analysis of rat serum suggest a more elaborative study for extended period of time.
\end{abstract}

Key Words: Apple pomace, rat feed, solid state fermentation, ethanol

\section{INTRODUCTION}

Apple pomace - a by-product of juice processing industry is a rich source of many nutrients including carbohydrates, minerals, fibres except protein (Sargent, 1984, Wang and Thomas, 1989). Its disposal in the environment, being highly biodegradable (very high BOD), results in production of foul smell and affects the aquatic life and ecosystem which compels for its proper treatment. Utilization of such a waste in an economical and effective way would be in the interest of prevention of resource wastage and better economy of the processing plants. Production of animal feed from apple pomace is one such proposition. Apple pomace has been utilized as an

\footnotetext{
* Author for correspondence
} 
animal feed as such or after ensilage (Smock and Neubert, 1950) but due to low digestible proteins was not considered suitable as an animal feed (Rumsey, 1978). Attempt to increase the quantity of protein was made by addition of non-protein nitrogen to apple pomace but it led to birth of dead or weak calves (Fotenote et al., 1977). The problem was overcome through fermentation and thus, manufacturing a high protein animal feed. The promising method included fermentation of apple pomace with yeasts, separating out ethanol and using the left-over protein rich material after drying as an animal feed. (Joshi and Sandhu, 1996). The major hurdle is to find out the acceptability of feed developed in appropriate animals by actual feeding trials. Limited reports are available on effect of feeding of fermented apple pomace to animals though study on feeding of single cell proteins to animals has been quite encouraging (Yacoub et al., 1990). Recently, feeding of fermented apple pomace to the broilers was found to be successful (Joshi et al., 2000). However, the acceptability of the animal feed with improved protein content made with seqential co-culture is not known. Keeping this in view, the present study was undertaken to find out the acceptability of the feed produced by fermentation of apple pomace and to study the effects of its feeding on rats.

\section{MATERIALS AND METHODS}

\section{Preparation of animal feed}

Apple pomace was fermented with conditions optimized earlier for sequential cultures (Joshi et al., 2000).Fermentation was carried out in plastic barrels with Candida utilis for $96 \mathrm{hrs}$ followed by Kloeckera spp. for $120 \mathrm{hrs}$ with intermittent rotation. After completion of fermentation and ethanol recovery, fermented apple pomace was dried in a mechanical dehydrator at $60^{\circ} \pm 1^{\circ} \mathrm{C}$ for $8 \mathrm{hrs}$ and was ground and packed in polythene bags. The powdered apple pomace was used for feed acceptability studies.

\section{Evaluation of feed in rats}

The albino rats, Rattus rattus (Rotan strain) procured from Central Research Laboratory, Kasauli, Solan (H.P.) were tested for the suitability of the animal feed (before and after reconstitution) in both "no choice" and "choice" experimental setup in the laboratory (Malhi and Sheikher,1988)

\section{Feeding of apple pomace}

\section{Before reconstitution}

Apple pomace either fermented or unfermented or after incorporation into the standard rat feed (in the ratio of 1:1) was fed to the rats for 2 weeks for no choice study and 6 days for choice study.

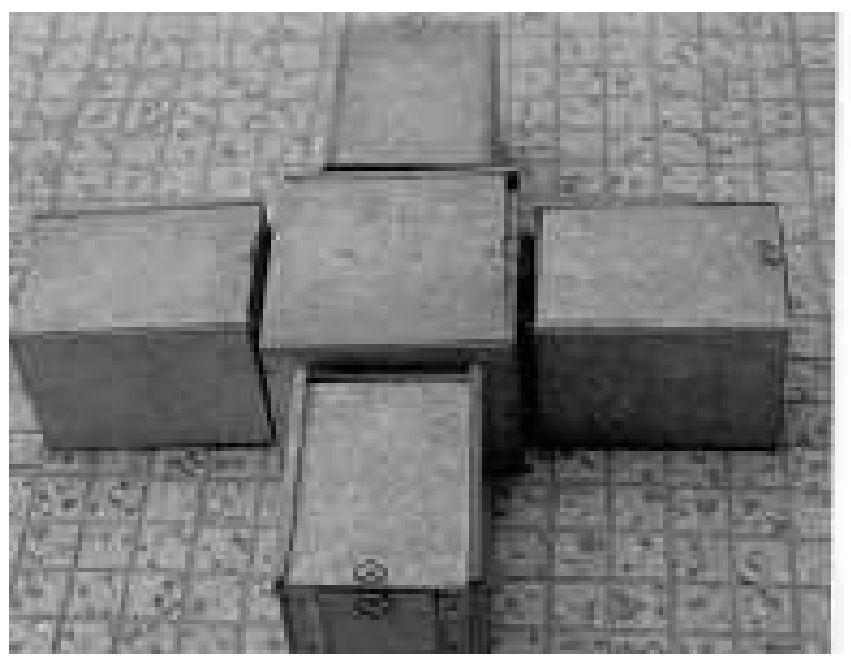

Figure 1 - Animal feed trial (choice) with white rats showing the cages used

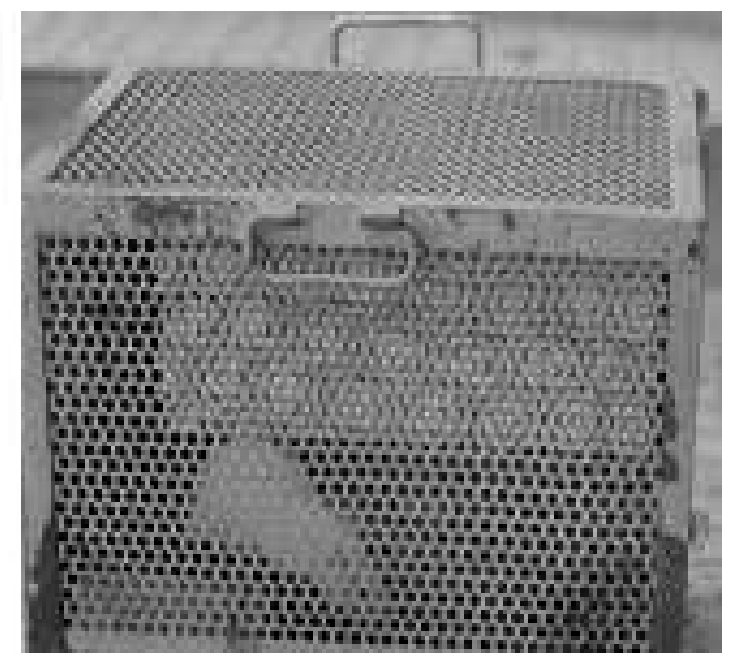

Figure 2 - Animal feed trial (no choice) with white rats, showing the cage used 
During feeding trial, weight of feed intake and faecal output were recorded at 24 hours interval in both the choice and no choice study while weight of animals were taken at weekly intervals in no choice study. Animals were divided into groups and were provided with different feeds.

\section{No choice study}

For no choice study, special type of individual cages were used as shown in Figs.1 and 2. Details of different type of feed given to rats before reconstitution in no choice study were:

BRNCF1-Standard rat feed, BRNCF2-100\% fermented apple pomace, BRNCF3-100\% unfermented apple pomace, BRNCF4-1:1 ratio of fermented apple pomace and standard rat feed, BRNCF5-1:1 ratio of unfermented apple pomace and standard rat feed.

\section{Choice study}

Choice experiment was conducted in plus maze by placing 3 food items at one time (one in each arm) and water in 4th arm. The order of placement of feeds and water was changed each day during the experiment. Water was provided $a d$ lib and each test was run for 5 days. Details of different types of feeds given to rats (choice studies) were:

BRCF1 - Standard rat feed, BRCF2 - 100\% fermented apple pomace ,BRCF3, 100\% unfermented apple pomace, 2. BRCF1 - Standard rat feed, BRCF4 - 1:1 ratio of fermented apple pomace and standard rat feed, BRCF5 - 1:1 ratio of unfermented apple pomace and standard rat feed.

\section{After reconstitution}

In a separate experiment the apple pomace after reconstitution was fed to the rats for a period of 2 weeks in no choice study and for 6 days in choice study as in the before reconstitution studies described earlier. Different types of feeds given to rats after reconstitution (No choice study) were:

ARNCF1 - Standard rat feed, ARNCF2 Fermented apple pomace $+2 \%$ ground nut oil + $10 \%$ jaggery $+0.1 \%$ mixed flavour $+1 \%$ salt, ARNCF3 - Fermented apple pomace $+10 \%$ jaggery $+0.1 \%$ mixed flavour $+2 \%$ salt, ARNCF 4 - Fermented apple pomace $+2 \%$ ground nut oil +
$0.1 \%$ mixed flavour $+1 \%$ salt, ARNCF5 Unfermented apple pomace $+2 \%$ ground nut oil + $10 \%$ jaggery $+0.1 \%$ mixed flavour $+1 \%$ salt, ARNCF6 - Unfermented apple pomace $+10 \%$ jaggery $+0.1 \%$ mixed flavour $+1 \%$ salt, ARNCF7 - Unfermented apple pomace $+2 \%$ ground nut oil + $0.1 \%$ mixed flavour $+1 \%$ salt.

Different type of feeds given to rats after reconstitution (choice study) were ARCF1 Standard rat feed, ARCF2 - Fermented apple pomace $+2 \%$ ground nut oil $+10 \%$ jaggery + $0.1 \%$ mixed flavour $+1 \%$ salt, ARCF3 Fermented apple pomace $+10 \%$ jaggery $+0.1 \%$ mixed flavour $+1 \%$ salt, ARCF1 - Standard rat feed, ARCF4 -Fermented apple pomace $+2 \%$ ground nut oil $+10 \%$ jaggery $+0.1 \%$ mixed flavour $+1 \%$ salt, ARCF5 - Unfermented apple pomace $+2 \%$ ground nut oil $+10 \%$ jaggery + $0.1 \%$ mixed flavour $+1 \%$ salt, ARCF1 - Standard rat feed, ARCF6 - unfermented apple pomace + $10 \%$ jaggery $+0.1 \%$ mixed flavour $+1 \%$ salt, ARCF7 - Unfermented apple pomace $+2 \%$ ground nut oil $+0.1 \%$ mixed flavour $+1 \%$ salt .

\section{Analysis}

\section{Efficiency of feed utilization}

The efficiency of different types of feeds given to the rats was analyzed on the basis of consumption index, growth rate, efficiency of conversion of ingested feed and digestibility of feed, as described by Waldbauer (1968).

$$
\begin{aligned}
& \text { Consumption index }=\frac{\text { Weight of feed eaten }}{\begin{array}{l}
\text { Mean weight of animal x Duration of } \\
\text { experiment during feeding trial }
\end{array}} \\
& \text { Growth rate(GR) }=\frac{\text { Weight gained by the animals }}{\begin{array}{l}
\text { Mean weight of animal x Duration of } \\
\text { feeding trial during feeding trial }
\end{array}} \\
& \begin{array}{l}
\text { Efficiency of conversion } \\
\text { of ingested feed (ECI) }
\end{array}=\frac{\text { Weight gained by animals }}{\text { Weight of feed ingested }} \times 100
\end{aligned}
$$

$\begin{aligned} & \text { Digestibility } \\ & \text { of feed (DIG) }\end{aligned}=\frac{\text { Feed ingested }- \text { Faecal matter }}{\text { Feed ingested }} \times 100$




\section{Blood Biochemical analysis}

The blood samples were collected from the rats after sacrificing them and different biochemical parameters of rat serum were analyzed. Total protein content in blood serum was determined by Biuerett method (Henry et al., 1974) by using analytical kits of Reckon diagnostic Pvt. Ltd., Baroda (India). Blood urea nitrogen (BUN) was calculated by End Point Dam method (Henry et al., 1974) by using analytical kits of J. Mitra and Co. Ltd., New Delhi (India). Glucose was determined by GOD/BOD method (Trinder, 1969 and Tietz, 1976) with the kits obtained from Span Dioagnostic Ltd., Surat (India). Alanine amino transferase (ALT) was calculated by 2, 4-DNPH method (Reitman and Frankel, 1957) by using kits of Span Diagnostic Pvt. Ltd., Surat (India). Aspartate aminotransferase (AST) was determined by 2, 4 DNPH method (Reitman and Frankel, 1957) by using kits of Span Diagnostic Pvt. Ltd., Surat (India).

\section{Statistical analysis}

The data of quantitative estimation of various physico-chemical characteristics of apple pomace and the data of evaluation of feeding trials were analyzed by completely randomized block design (CRD) for factorial analysis (Cochran and Cox, 1963).

\section{RESULTS AND DISCUSSION}

\section{Feeding before reconstitution}

\section{No choice study}

It is clear from the results (Fig. 3) that the feed intake in all the groups increased throughout the trial (for two weeks) except BRNCF2 group where the feed intake decreased continuously and as a result all the rats died.

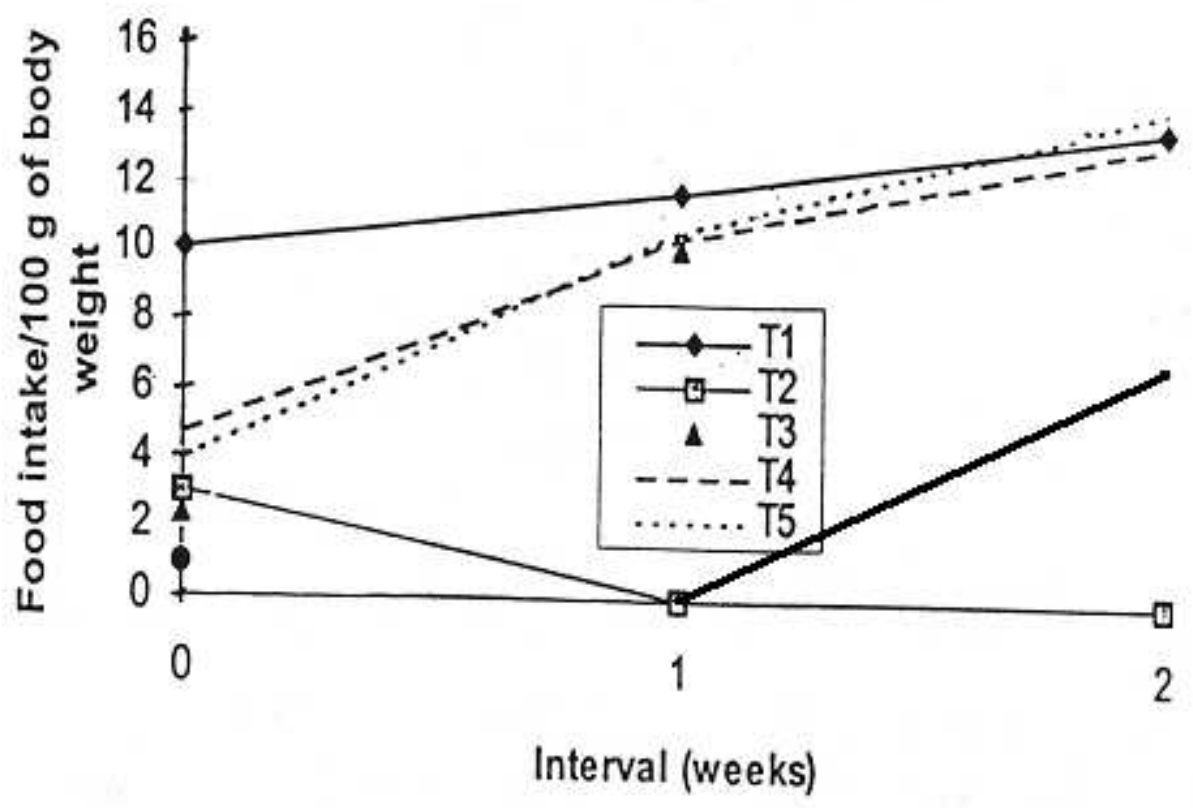

Figure 3 - Different types of food intake (no choice) per $100 \mathrm{~g}$ of body weight of animal.

The decrease in feed intake in this group might be due to variation in flavour and appearance of the feed than the standard rat feed and subsequent deaths, may be due to starvation and decreased digestibility. Indirectly, it suggests that certain essential nutrient required for the survival of rats, may be lacking in the feed. However, in BRNCF3 group feed intake was normal for one week but the animal failed to utilize the consumed feed probably due to high fiber content thus, decreasing the feed intake after a week. 
Increase in plasma enteroglucagon (EG) levels in rats fed readily fermentable dietary fibre took place (Gee et al.,1996) which is supposed to downregulate gastrointestinal motility and suppress gastric acid secretion (Schjoldager et al., 1989) which might be the reason for decreased digestibility of both forms of apple pomace in our study. A reference to the standard diet of rat (Table 1) indicated higher crude fibre content in the fermented apple pomace which further substantiated our hypothesis.
Table 1 - Composition of standard rat feed

\begin{tabular}{lr}
\hline \multicolumn{1}{c}{ Constituents } & $\begin{array}{c}\text { Dry weight } \\
\text { basis (\%) }\end{array}$ \\
\hline Crude protein & 21.0 \\
Ether extract & 5.0 \\
Crude fibre & 4.0 \\
Ash & 8.0 \\
Calcium & 1.0 \\
Phosphorus & 0.6 \\
Nitrogen Free Extract & 53.0 \\
Metabilisable Energy $(\mathrm{K} \mathrm{cal} / \mathrm{Kg})$ & 3600.0 \\
\hline
\end{tabular}

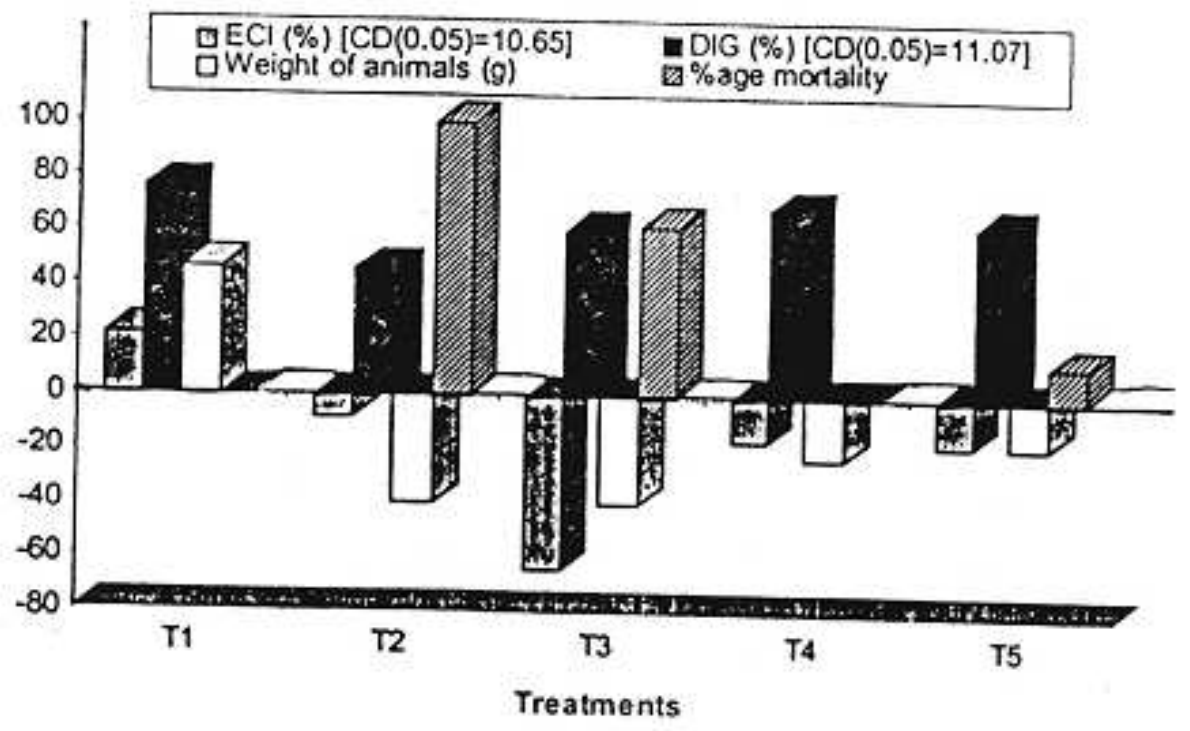

ECI - Efficiency of conversion of ingested food

DIG - Digestibility

T1: Standard rat animal feed BRNCF1

T2: $100 \%$ fermented apple pomace BRNCF2

T3: $100 \%$ unfermented apple BRNCF3

T4: $1: 1$ standard rat feed and 100\% fermented apple pomace BRNCF4

T5: 1:1 standard rat feed and 100\% unfermented apple pomace BRNCF5

Figure 4 - Effect of different feeds on efficiency of conversion of digested feed (\%), digestibility $(\%)$ and weight of animals $(\mathrm{g})$ of white rats.

The results pertaining to digestibility (DIG), efficiecy of conversion of ingested feed (ECI) weight of animals (WA) and mortality in different feed groups of rat (Fig. 4) showed significant differences in all the parameters. Highest digestibility of feed was observed in BRNCF1 group, whereas it was lowest in BRNCF2 group. The digestibility in other groups, BRNCF3,
BRNCF4 and BRNCF5 were almost comparable though lower than the standard rat feed in terms of absolute values. Similar decrease in digestibility of potato processing waste in ruminants (Arora et al.,1995) and fermented orange peels and grape distillery stalks have also been reported (Nicoloni et al., 1993). 
The decrease in digestibility of apple pomace or fermented apple pomace might be due to the reasons described earlier. Furthermore, the ECI values in all the feed groups were negative except in the standard rat feed group. Less availability of essential nutrients required for basal metabolism might have led to negative ECI, hence loss of body weight. No death was observed in BRNCF1 and BRNCF4 groups, whereas the highest (100\%) mortality was observed in BRNCF2 group which might be due to starvation and indigestibility. A lower mortality $(62.5 \%)$ in BRNCF3 group, and $(12.5 \%)$ in BRNCF5 group might be due to the inability of the animals to utilize the ingested feed as revealed by the post-mortem examination (Figs. 5 and 6).There were also significant differences in the consumption index and growth rate in different feed groups. The highest consumption index was in BRNCF1 followed by BRNCF4 and BRNCF5 group feed. The lowest consumption index, observed in BRNCF2 group might also be the result of poor acceptability of the feed. It is thus, clear that the growth rates were negative in all the feed groups except the BRNCF1 group.

\section{Choice studies}

It is clear from the Figs. 7 and 8 that the BFCF1 feed was more acceptable than others followed by BRCF4 and BRCF5 feeds. The apple pomace either fermented or unfermented had least acceptability probably due to undesirable odour of the feed. Furthermore, both BRCF4 and BRCF5 feeds were more acceptable than the feed given alone.

These findings indirectly point out towards the need of some sort of blending or reconstitution of feed comprising of apple pomace to make a balanced and attractive feed for rats. The results on choice studies of animal feed on rats with apple pomace were similar to that of no-choice studies with respect to fermented or unfermented apple pomace. Overall, it is apparant that the apple pomace either fermented or unfermented alone is not acceptable but can be made so after reconstitution.

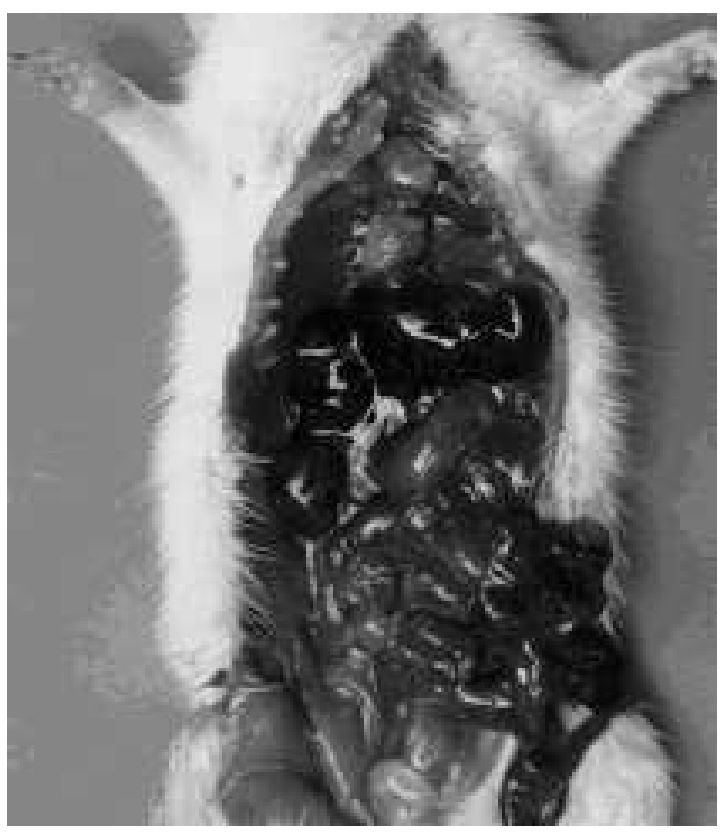

Figure 5 - Empty intestine and undigested food material in stomach of white albino rats fed with 100 per cent fermented apple pomace.

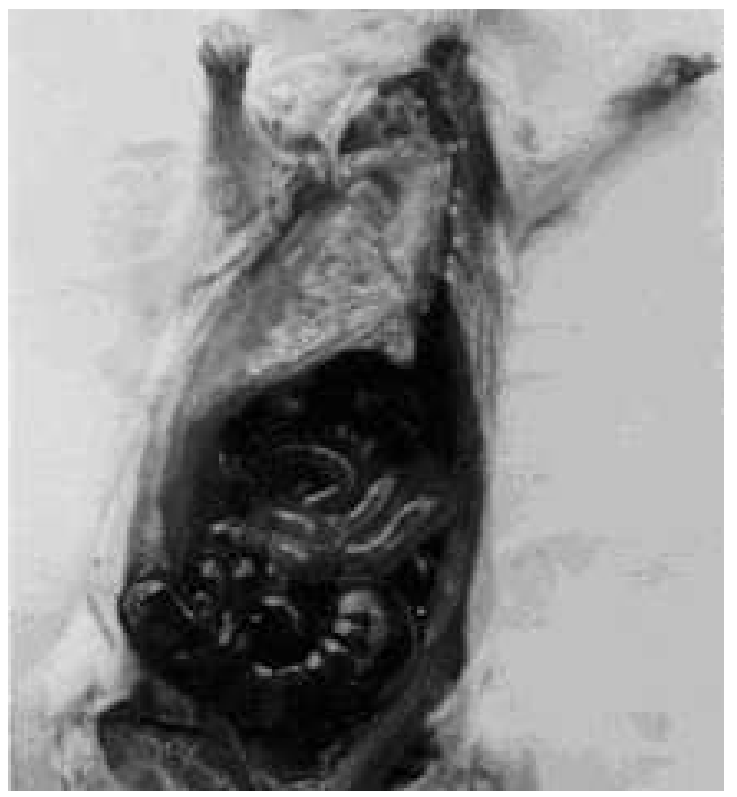

Figure 6 - Undigested food material filled in the stomach of white rats fed with 100 per cent unfermented apple pomace. 


\section{Feeding after reconstitution}

\section{No choice studies}

Both fermented and unfermented apple pomace after reconstitution, were fed to the rats and their results are depicted in Figs. 11 and 12. The feed intake (per $100 \mathrm{~g}$ body weight of rats) of different feed groups was found to be significant.It was the highest in ARNCF1 group followed by ARNCF6 group closely followed by ARNCF2 and ARNCF4 groups. The lowest feed intake was observed in ARNCF7 group which decreased suddenly after one week of feeding.

The digestibility and ECI in different feed groups was found to be non-significant though weight of animals was significant. Digestibility and ECI of the reconstituted feed comprising of fermented and unfermented apple pomace however were comparable to the standard rat feed. Thus, reconstituted feed comprising of apple pomace either fermented or unfermented gives better results on DIG and ECI than the apple pomace either fermented or unfermented given as such or after incorporation of both into the standard rat feed in the ratio of $1: 1$. The digestibility of reconstituted feed containing apple pomace in our study was similar to the digestibility of apple pomace recorded earlier (Singh and Narang, 1992).

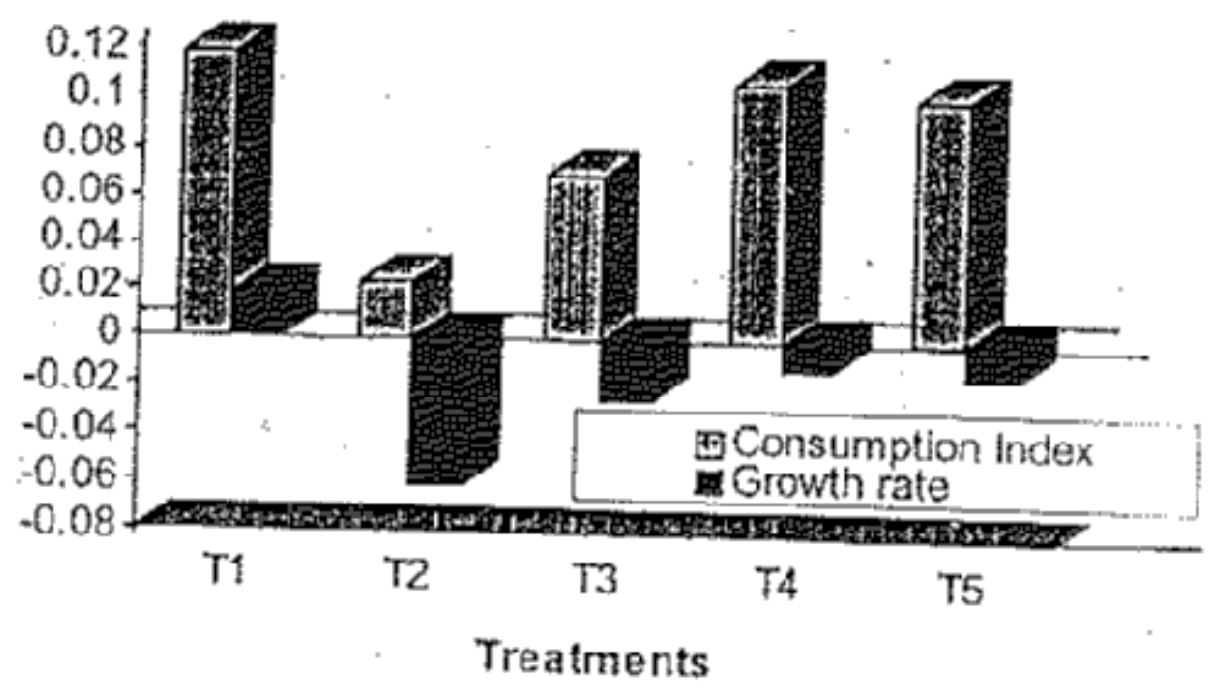

$\mathrm{CD}(0.05)$ : Consumption Index $=0.019 ;$ Growth rate $=0.01$

Figure 7 - Effect of different feeds on growth rate and consumption index of white rats.

A perusal of results on DIG and ECI and weight gained revealed that the maximum weight gain was recorded in ARNCF1 group followed by the ARNCF2 group while the lowest weight gain was observed in ARNCF4 group.The results indicate that there is loss of carbohydrates during fermentation so addition of jaggery is a must in the reconstitution of fermented apple pomace for feeding the rats. Similar to these observations, effect of feeding of single cell proteins as replacement upto 50 per cent of feed on the body weight of Karadi lambs has been reported (Yacoub et al., 1990). Earlier feeding of Saccharomyces cerevisiae yeast alongwith the medium to buffaloes considerably increased their milk yield (Kumar et al., 1992). 


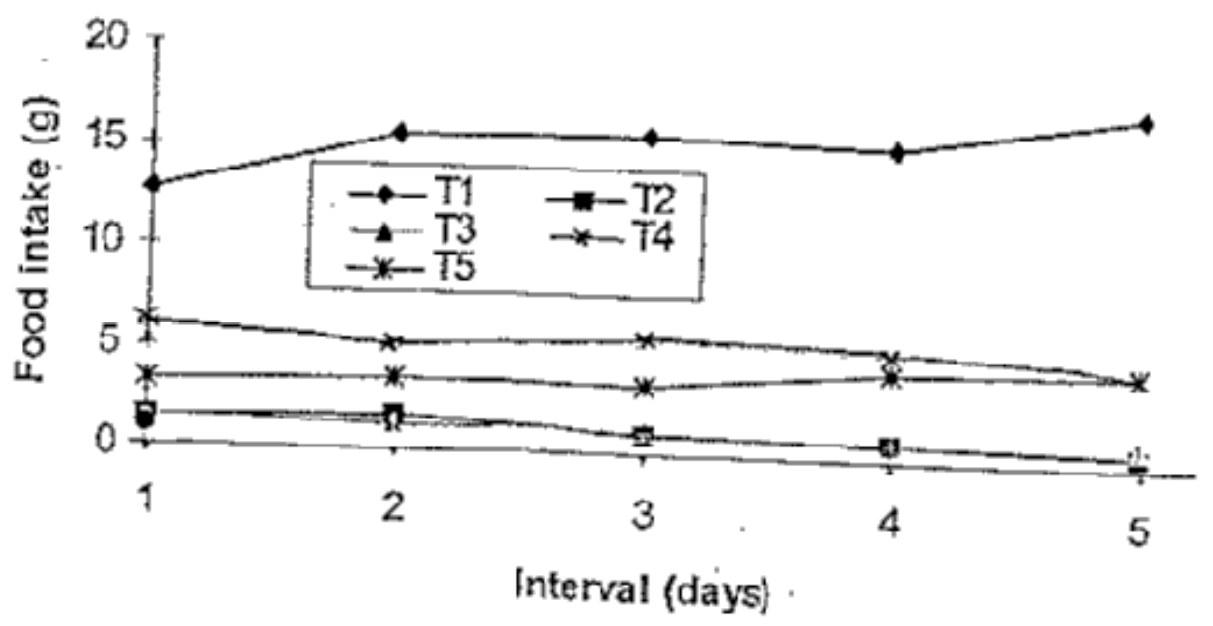

T1: Standard rat animal feed BRCF1

T2: $100 \%$ fermented apple pomace BRCF2

T3: $100 \%$ unfermented apple BRCF3

T4: 1:1 standard rat feed and 100\% fermented apple pomace BRCF4

T5: 1:1 standard rat feed and 100\% unfermented apple pomace BRCF5

Figure 8 - Different types of food intake (g) (choice).

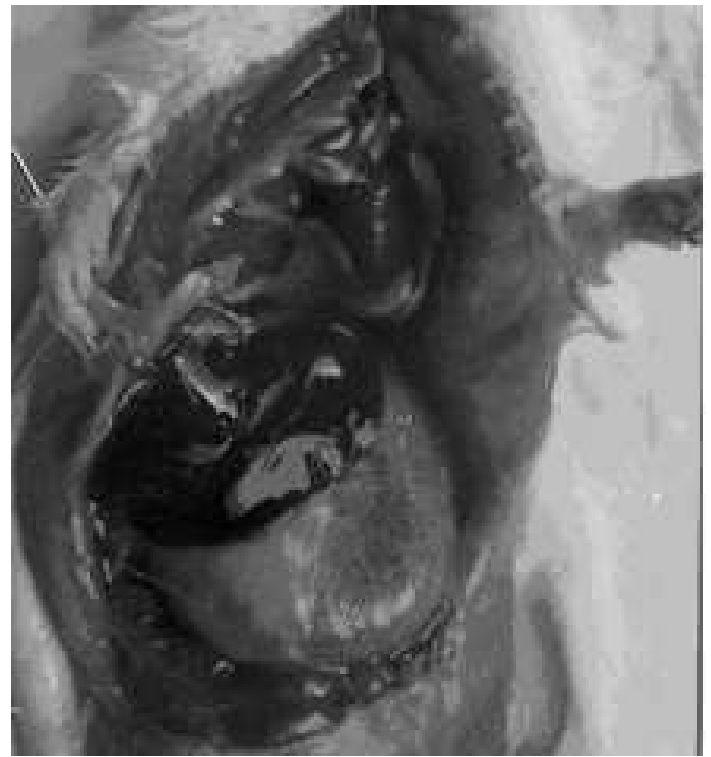

Figure 9 - Digested food material with liver damage of white rats fed with reconstituted fermented apple pomace comprising of 10 per cent jaggery, 0.01 per cent mixed flavour and 1 per cent salt.

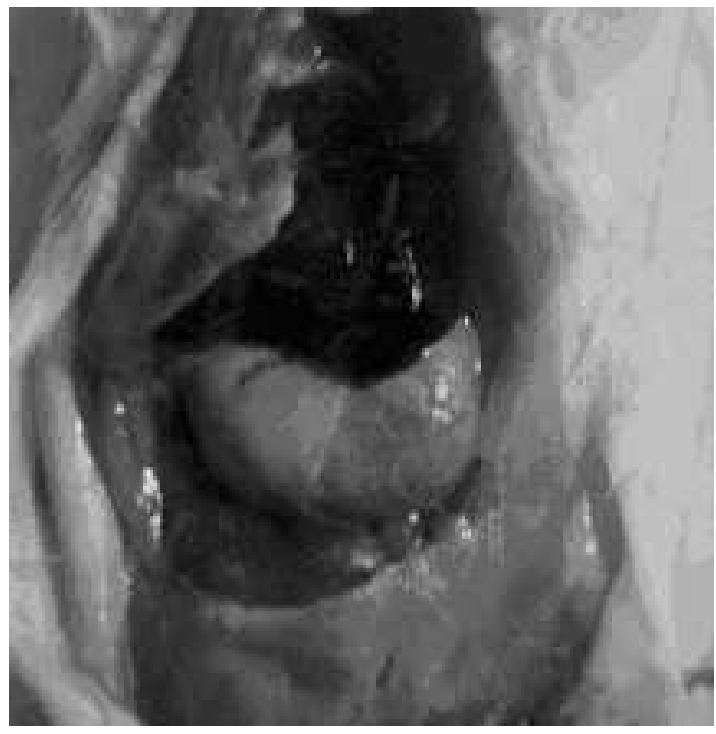

Figure 10 - Digested food material in stomach with liver damage of white rats fed with reconstituted fermented apple pomace comprising of 10 per cent jaggery, 2 per cent ground nut oil, 0.01 per cent mixed flavour and 1 per cent salt. 


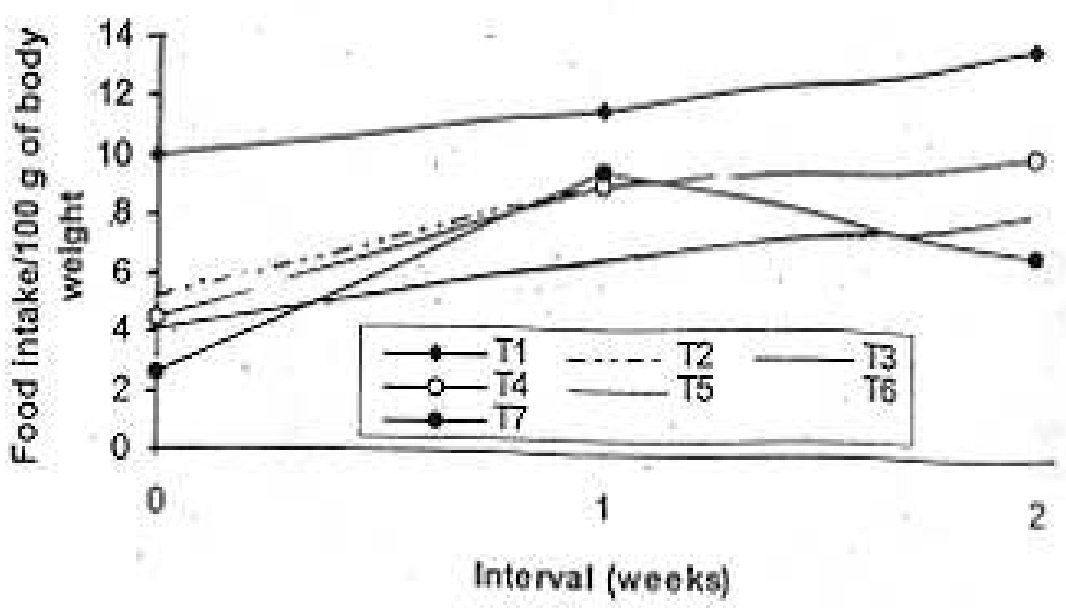

Figure 11 - Different types of food intake (no choice) per 100g of body weight of animal.

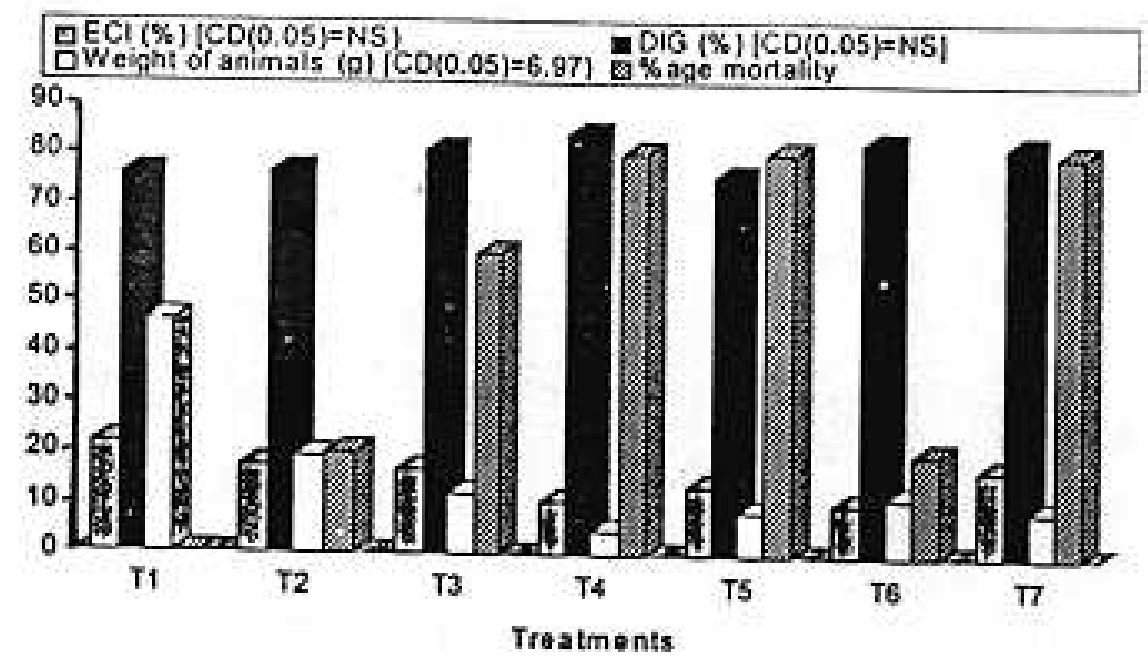

ECI - Efficiency of conversion of ingested food

DIG - Digestibility

T1: Standard rat animal feed ARNCF1

T2: Fermented AP $+2 \%$ ground nut oil $+10 \%$ jaggery $+0.01 \%$ mixed flavour $+1 \%$ salt ARNCF2

T3: Fermented AP $+10 \%$ jaggery $+0.01 \%$ mixed flavour $+1 \%$ salt ARNCF3

T4: Fermented AP $+2 \%$ ground nut oil $+0.01 \%$ mixed flavour $+1 \%$ salt ARNCF4

T5: Unfermented AP $+2 \%$ ground nut oil $+10 \%$ jaggery $+0.01 \%$ mixed flavour $+1 \%$ salt ARNCF5

T6: Unfermented AP $+10 \%$ jaggery $+0.01 \%$ mixed flavour $+1 \%$ salt ARNCF6

T7: Unfermented AP $+2 \%$ ground nut oil $+0.01 \%$ mixed flavour $+1 \%$ salt ARNCF7

Figure 12 - Effect of different feeding on efficiency of conversion of digested feed (\%), digestibility (\%) and weight of animals ( $\mathrm{g})$ of white rats 
Consumption index in different feed groups was non-significant but growth rate in different feed groups was significant (Fig. 13). The highest growth rate was observed in ARNCF1 group followed by ARNCF2 and ARNCF4 groups while the lowest was observed in ARNCF5 group. The maximum mortality $(80 \%)$ was observed in unfermented apple pomace with $2 \%$ oil, $0.01 \%$ t mixed flavour and $1 \%$ salt. The detailed postmortem examination (PME) of rats that died in the different groups revealed generalized oedema which probably be due to some hepatotoxin in the ingredients used for reconstitution of the feed.

\section{Choice studies}

The results in Fig. 14 reveal that amongst the different types of reconstituted feeds, the ARCF2 feed was the most acceptable after ARCR1 feed. The acceptability ie of other reconstituted feeds were very low as compared to ARCF1 and ARCF2 while the differences amongst the reconstituted feeds were marginal. The DIG, ECI, WA and GR values of reconstituted feeds were more or less comparable with the standard rat feed. Amongst the reconstituted feeds ARCF2, gave the best results.
Thus, the reconstituted feed has been brought to the acceptability level of that of standard rat feed but further work is required to study the long term effects.

\section{Blood biochemical analysis}

\section{Glucose}

Results (Table 2) indicate that in the standard rat feed group the serum glucose level was within the normal range (Raguramulu et al., 1983), whereas in all the other groups hypoglycemia (decrease in blood glucose level) was observed as compared to the control except in the feed comprising of unfermented apple pomace with $10 \%$ jaggery, $2 \%$ oil, $0.01 \%$ flavour and $1 \%$ salt. The reason seems to be the availability of more sugar in this feed than others fermented apple pomace based feeds as carbohydrates are lost during fermentation as described earlier. The decrease in serum glucose levels of other groups might be due to liver damage as it was evident on the PME, leading to impaired glucose metabolism.

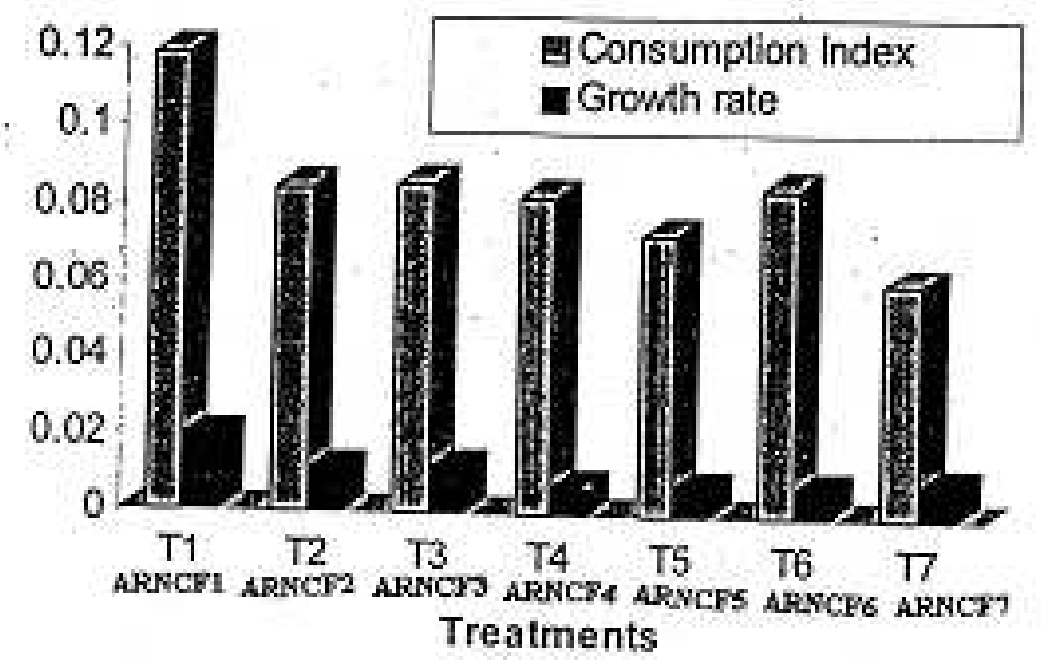

$\mathrm{CD}(0.05)$ : Consumption Index $=$ NS; Growth rate $=0.005$

Figure 13 - Effect of different feeding on growth rate and consumption index of white rats 


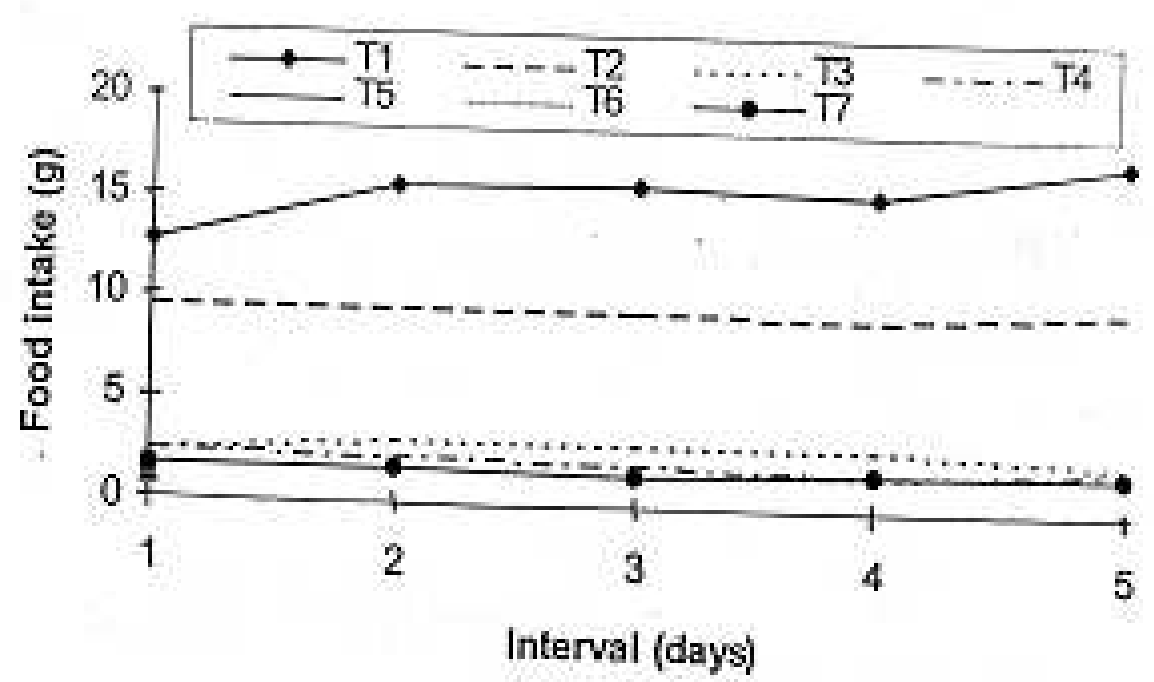

T1: Standard rat animal feed ARCF1

T2: Fermented AP $+2 \%$ ground nut oil $+10 \%$ jaggery $+0.01 \%$ mixed flavour $+1 \%$ salt ARCF2

T3: Fermented AP $+10 \%$ jaggery $+0.01 \%$ mixed flavour $+1 \%$ salt ARCF3

T4: Fermented AP $+2 \%$ ground nut oil $+0.01 \%$ mixed flavour $+1 \%$ salt ARCF4

T5: Unfermented AP $+2 \%$ ground nut oil $+10 \%$ jaggery $+0.01 \%$ mixed flavour $+1 \%$ salt ARCF5

T6: Unfermented AP $+10 \%$ jaggery $+0.01 \%$ mixed flavour $+1 \%$ salt ARCF6

T7: Unfermented AP $+2 \%$ ground nut oil $+0.01 \%$ mixed flavour $+1 \%$ salt ARCF7

Figure 14 - Different types of food intake (g) (choice)

Table 2 - Serum biochemical changes in rat during the feeding

\begin{tabular}{cccccc}
\hline Treatments & $\begin{array}{c}\text { Glucose } \\
(\mathbf{m g} \%)\end{array}$ & $\begin{array}{c}\text { Blood urea } \\
\text { nitrogen } \\
(\mathbf{m g} \%)\end{array}$ & $\begin{array}{c}\text { Total proteins } \\
(\mathbf{g} \%)\end{array}$ & $\begin{array}{c}\text { ALT } \\
(\mathbf{I U})\end{array}$ & $\begin{array}{c}\text { AST } \\
(\mathbf{I U})\end{array}$ \\
\hline $\mathrm{T}_{0}$ & $50-135$ & $5-29$ & $4.7-8.2$ & $46-81$ & 18.30 \\
$\mathrm{~T}_{1}$ & 52.00 & 14.01 & 6.50 & 50.00 & 40.00 \\
$\mathrm{~T}_{2}$ & 20.00 & 22.40 & 7.08 & 304.00 & 170.00 \\
$\mathrm{~T}_{3}$ & 15.00 & 18.68 & 7.10 & 380.00 & 184.00 \\
$\mathrm{~T}_{4}$ & 15.00 & 18.68 & 7.50 & 230.00 & 97.00 \\
$\mathrm{~T}_{5}$ & 50.00 & 25.68 & 8.02 & 236.00 & 170.00 \\
$\mathrm{~T}_{6}$ & 25.00 & 42.96 & 7.40 & 270.00 & 60.00 \\
$\mathrm{~T}_{7}$ & 15.00 & 41.00 & 7.46 & 260.00 & 160.00 \\
\hline
\end{tabular}

\footnotetext{
* These results pertain to after reconstitution no choice feed studies.

$\mathrm{T} 0=$ Normal rat blood serum ranges .

$\mathrm{T} 1=$ Standard rat feed .

$\mathrm{T} 2=$ Fermented apple pomace $+2 \%$ ground nut oil $+10 \%$ jaggery $+0.01 \%$ mixed flavour $+1 \%$ salt

$\mathrm{T} 3=$ Fermented apple pomace $+10 \%$ jaggery $+0.01 \%$ mixed flavour $+1 \%$ salt

$\mathrm{T} 4=$ Fermented apple pomace $+2 \%$ ground nut oil $+0.01 \%$ mixed flavour $+1 \%$ salt

T5 $=$ Unfermented apple pomace $+10 \%$ jaggery $+2 \%$ ground nut oil $+0.01 \%$ mixed flavour $+1 \%$ salt

$\mathrm{T} 6=$ Unfermented apple pomace $+10 \%$ jaggery $+0.01 \%$ mixed flavour $+1 \%$ salt

$\mathrm{T} 7=$ Unfermented apple pomace $+2 \%$ ground nut oil $+0.01 \%$ mixed flavour $+1 \%$ salt

$\mathrm{ALT}=$ Alanine amino transferase .

$\mathrm{AST}=$ Aspartate amino transferase.
} 


\section{Blood urea nitrogen (BUN)}

BUN levels of rat serum in all the treatments including standard rat feed fed group were within the range of BUN level of normal rat serum (Table 2). However, a non-specific increase in BUN in the feed comprising of unfermented apple pomace with or without jaggery, 0.01 per cent mixed flavour and 1 per cent salt and unfermented apple pomace with $2 \%$ oil, $0.01 \%$ mixed flavour and $1 \%$ salt was observed. Increase in BUN level indicates kidney damage but in our study no kidney damage was observed on post-mortem examination. Thus, it might be due to decreased utilization of urea by damaged liver.

\section{Total proteins}

The results (Table2) show that the total protein serum levels in all the treatments were within the normal range (Raguramulu et al. 1983). Normally, the decrease in serum total protein is observed in chronic liver damage, whereas, in our study there was acute liver damage resulting in a sudden death.

\section{ALT and AST}

The serum AST and ALT levels in the different groups (Table 2) show that the levels in the standard rat feed fed groups were within the normal range. However, in all the other treatments ALT and AST levels were higher which might be due to liver damage which was evident on PME (Figs. 9 and 10). The increased ALT and AST levels in the serum of rats could be attributed to liver damage at cellular level (Drotman and Lohorn, 1978) and also due to increased plasma membrane permeability (Ramazzatto and Carlin, 1978) as a result these enzymes are liberated in the blood serum. The blood biochemical studies reveal the presence of some toxic substance in the feed which led to sudden liver damage. These results corroborated with PME findings as explained earlier.

It is apparent from the complete study that feed after reconstitution and standard rat feed had highest acceptability followed by $1: 1$ ratio of standard rat feed and fermented apple pomace. The feeding of fermented or unfermented apple pomace as such to the rats was least acceptable ; leading to negative growth parameters. The reconstituted feed with fermented apple pomace with $10 \%$, jaggery, $2 \%$ oil, $0.01 \%$ mixed flavour and $1 \%$ salt was the most acceptable and gave the best growth parameters of rats studied. The post-mortem examination of rats that died after consumption of reconstituted feed containing either fermented or unfermented apple pomace, revealed liver damage as the cause of death which may probably be due to some toxins in the additives used for reconstitution of feed. The biochemical analysis of blood samples of rats fed with reconstituted feed also indicated liver damage which was evident in the form of increased ALT and AST levels. In an earlier study,the apple pomace based feed when mixed with standard broiler feed in the ratio of 1:1 was acceptable to the broilers, they gained weight regularly, no mortality was observed and no abnormal lesions were observed in liver and kidney indicating no toxicity (Joshi et al., 2000). An overview of the results on feeding trial in broilers and rats indicate that rats might be having low levels of enzymes required for utilization of feed high in fibres as in apple pomace, compared to the broilers which could make use of such feeds Thus, it seems that more elaborated studies with different animal spp. for extended period of time with different formulations based on apple pomace is needed to decide the suitability of such feed especially the long term effects on the animals.

\section{RESUMO}

Para utilizar bagaço de maçã de uma maneira econômica e eficaz, foi desenvolvido um processo por fermentação no estado sólido (SSF) que utiliza uma co-cultura interativa seqüencial de Cândida utilis e Kloechera. Remoção do etanol foi realizado através da secagem do bagaço de maçã. Os testes com o bagaço de maçã fermentado ou não foram feitos em ratos brancos em um experimento delineado. Os resultados mostraram que o bagaço de maçã fermentado ou não se mostraram aceitáveis sendo que os mesmos apresentaram uma digestibilidade inferior a ração comum. Quando o estudo alimentando os ratos utilizando $100 \%$ de bagaço de maçã fermentado e não fermentado e alterando a concentração progressivamente, observou-se a morte dos ratos aparentemente devido a uma redução da digestibilidade em razão da alta concentração em fibras. Em comparação com o grupo padrão, as taxas de crescimento foram negativas em todos os grupos estudados. A mistura 
da ração padrão com o bagaço de maçã fermentado na proporção 1:1, proporcionou maior aceitabilidade e digestibilidade. A mistura do bagaço de maçã fermentado com $10 \%$ de 'jagerry', $2 \%$ de óleo de 'groundnut', $0,01 \%$ de aromas e $1 \%$ de sal foi o mais aceitável. O exame pós-morte dos ratos que receberam a dieta durante sua alimentação apresentou edema generalizado, provavelmente devido a alguma hepatotoxina na alimentação. O nível de glicose no sangue do grupo alimentado com bagaço de maçã, exceto misturado com 'jagerry', mostrou uma hypoglicemia geral. A taxa de mortalidade, o exame pós-morte dos ratos que morreram durante o experimento e a análise bioquímica do sangue e do soro sugerem um estudo mais elaborativo e mais prolongado.

\section{REFERENCES}

Arora, M.; Wadhwa, M.; Thapar, V. K. and Sehgal, V. K. (1995), In-vivo evaluation of fermented potato processing waste as ruminant feed. Indian $J$. Microbiol., 35 : (3), 259-261.

Cockrane, W. G. and Cox, G. M. (1963), Experimental Designs. $14^{\text {th }}$ ed. Asia Publ. House, Bombay. pp. 163.

Drotman, R. B. and Lowhorn, G. T. (1978), Serum enzymes as indicator chemically induced liver damage. Drug. Chem. Toxicol., 1, 163-171.

Fotenote, J. P.; Bovard, K. P.; Oltgen, R. R.; Rumsey, T. S. and Driode, B. M. (1977), Supplementation of apple pomace with non-protein nitrogen for gestating cows. J. Anim. Sci., 46, 513-522.

Gee, J. M.; Lee-Finglas,W.; Wortley, G. W. and Jonson. I. T. (1996), Fermentable non-absorbed carbohydrates modify the gastro-instestinal endocrine reponse to food in rats and in human subjects. In: Fenwick, G. R.; Hedley, C.; Richards, R. L. and Khokhar, S. (eds.). Agric. Food Quality. An Interdisciplinary Approach. The Royal Society of Chemistry, Cambridge, U. K. pp. 404.

Hang, Y. D. (1988), Improvement of the nutritional value of apple pomace fermentation. Nutr. Rep. Internat., 38, 207-209.

Henry, R. J.; Cannon, D. C. and Winkelman, J. L. (1974), Clinical chemistry, principles and techniques. $2^{\text {nd }}$ ed. Harper and Row, Publications.

Joshi, C. and Joshi, V. K. (1990), Food processing waste management technology - Need for an integrated approach. Indian Food Packer, 46 : (5), 56-57.
Joshi, V. K.; Gupta, K.; Devarajan, A.; Lal, B. B. and Arya, S. P. (2000), Production and evaluation of fermented apple pomace feed in broilers. J. Food. Sci. Technol., 37 : (6), 609-612.

Joshi, V. K. and Sandhu, D. K. (1996), Preparation and evaluation of an animal fed by-product produced by solid state fermentation of apple pomace. Bioresouruce Technol., 56, 251-255.

Joshi, V. K.; Devarajan, A. and Sharma, N. (2000), Interactive co-culture system for the production of ethanol and animal feed from apple pomace. [Submitted].

Kumar, U.; Soneen, V. K. and Singh, S. (1992), A note on the effect of supplementation of yeast culture (Saccharomyces cerevisiae plus growth medium) in the diet of buffaloes on milk yield and composition. Animal Production, 55 : (3), 440-442.

Malhi, C. S. and Sheikher, C. (1988), Food Preference Behaviour of Bandicota bengalensis. In: Saxena, A. C. and Saxena, V. C. (eds.). Proceeding of $8^{\text {th }}$ National Symposium on Life Science. Merut Publications, Kanpur. pp. 123-125.

Nicolini, L.; Volpe, C.; Pezotti, A. and Cavilli, A. (1993), Changes in-vitro digestibility of orange peels and distillery grapes stalks after solid substrate fermentation by higher fungi. Bioresource Technol., 45, 17-20.

Raguramulu, N.; Madhvan, Nair, K. and Kalyanasundaram, S. (1983), A manual of laboratory techniques. Silver Prints. Hydrabad, India. pp. 276.

Rahmat, H.; Hodge, R. A.; Manderson, G. J. and Yu, P. L. (1995), Solid substrate fermentation of Kloeckera apiculata and Candida utilis on apple pomace to produce an improved feed stock. World $J$. Microbiol. Biotechnol., 11, 168-170.

Ramazzotto, L. J. and Carlin, R. (1978), Effects of DMSO on SGOT during hypothermia in adrenalectomized rats. Life Sci., 22, 329-336.

Ramsey, T. S. (1978), Ruminal fermentation products and plasma ammonia of fistulated steers fed apple pomace diets. J. Anim. Sci., 47, 967-976.

Reitman, S. and Frankel, S. (1957), Am. J. Clin. Path., 28, 56.

Sandhu, D. K. and Joshi, V. K. (1997), Solid state fermentation of apple pomace for concomitant production of ethanol and animal fed. J. Sci. Industrial Res., 56, 86-90.

Sargent, S. A. (1984), An energy and cost analysis model to evaluate the combustion of food processing wastes. Ph.D. Thesis, Department of Agriculture Engineering, Michigan State University, E. Lansing, MI.

Schjoldagev, B.; Mortensen, P. E.; Myhre, J.; Christiasen, J. and Holst. J. J. (1989), Dig. Dis. Sci., 34, 1411. 
Singh, B. and Narang, M. P. (1992), Studies on the ruman degradation kinetics and utilization of apple pomace. Bioresource Technol., 39 : (3), 233-240.

Smock, R. M. and Neubert, A. M. (1950), Apple and Apple Products. Interscience. Publishers, New York.

Tietz, W. W. (1976), In: Saunders, W. B. Clinical Guide to Laboratory Tests. Co. Philadelphia. pp. 238.

Trinder, P. (1969), Am. Clinp. Biochem., 6, 24.

Waldbauer, G. P. (1968), The consumption and utilization of feed by insects. In: Advances in Insect Physiology., 5, 229-282.

Yacoub, S. E.; Kashmula, U. Y. and Naseer, R. H. (1990), Effect of using single cell proteins on growth and carcass characteristics of Karadi lambs. Mesopotamia. J. Agric., 22, 153-169.

Received: September 20, 2001; Revised: April 25, 2002; Accepted: May 15, 2003. 